\title{
Physical demands during the hauling of fishing nets for artisan fishing using rafts in beach of Ponta Negra, Natal-Brasil
}

\author{
Anelena Jaeschke ${ }^{\mathrm{a},{ }^{*}}$ and Maria Christine Werba Saldanha ${ }^{\mathrm{b}}$ \\ ${ }^{a} U F R N$ - Federal University of Rio Grande do Norte, Campus Universitário, Lagoa Nova, Technology Center, \\ Production Engineering Programme-PEP, Room 48, CEP: 59.072-970, Lagoa Nova, Natal, RN, Brazil. Tel/fax: + \\ 55 (0xx84) 8770-7861
}

\begin{abstract}
The current article aims to analyse the activity and the repercussions in the health of the artisan fishermen who use rafts in the urban Beach of Ponta Negra in Natal - RN, with emphasis on the physical demands at the step of hauling the nets from the ocean. It has been taken as a reference the methodology of Work Ergonomic Analysis-WEA. 21 fishermen participated in the study (50\% of the population). It was used applying observational techniques and methodologies (open and sistematic observations and simulations) interactional ( social and economic questionnaire, conversational actions, verbalizations, self confrontations and collective analysis) and health assessment (static postural assessment, movement flexibility of flexo extension of the shoulder and the ischiotibial muscle, lumbar region and hang grip. Applying the diagram of painful areas and the Nordic Questionnaire of mucleskeletal symptoms). The results were submeted to restitutions and validations with the raftmen. The hauling of the nets represents a high muscleskeletal risk, joining physical effort, adopting forced postures with the rotation of the spine and movement repetition, mainly flexo extension of vertebral spine, aggravated by the demand of strength fo the stabilizing muscles of the human body to keep the poise. The impacts of the activity of the fisherman of Ponta Negra, related to postures and strength demand were observed in the postural assessment and are related to the activity.
\end{abstract}

Keywords: ergonomics, artisanal fishery; rafts, physical demands, health assessment

\section{Introduction}

In Brazil, sea fishing responds for 580 thousand of fish caught a year. In 2007, the northeastern region caught $28,8 \%$ of national production, out of which 96,3 were from artisan fishing, which makes the fleet of that region the least industrialized of the country. [15] Rio Grande do Norte has a $410 \mathrm{~km}$ coastline, 25 coastal towns, 97 fishing communities and an estimated contingent of 13.000 raftsmen who perform the fishing for subsistence and commerce. $28,5 \%$ (1071) of the State fleet are rafts and paquetes (smaller rafts) which caught $12,10 \%$ of the annual fish in 2007 (2174t). [14]. The Z-04 Colony of fish and aquiculture in Natal has 381 registered vessels, out of which $22,8 \%(87)$ are rafts. In the beach of
Ponta Negra, the area of the current study, there are 31 rafts and 42 raftsmen.

Artisan fishing is the one which occurs through manual work performed by the raftsmen, using small vessels in the capture and in small scale [26,25]. The raft is a secular vessel used in artisan fishing and named according to its dimensions. The small-sized ones are called botes or catraias, measuring around 3.5 meters; the medium-sized ones are knowns as paquetes , 4 to 5 meters length; the jangada de alto is the model that reaches 8 meters length. [21].

Artisan fishing presents highly risky and unpredictable situations and features: the use of poor work tools, difficult inhabitability, physical overload and high energy consumption, risk of accidents and incidents, improper handling of fish, interference from urban and tourism growth, which increases the situa-

*Corresponding author: email: cwerbasaldanha@gmail.com 
tion of insecurity and requires adequate and continuous replanning. [11,24,8,7,22].

The activity itself is tiring, demands physical strength, forced postures and affects the health of artisan raftsmen, as it has been demonstrated in several researches which show: damage to spine because of the effort required to pull and take rafts to the ocean [5]; - muscular and lesions and accidents with fractures caused by forced postures and body movements, which makes it difficult or impossible for the raftsmen to carry his tasks. [5]; frequent complaints about neuromuscular and articular pains in the wrists, arms, shoulders, back, chest, spine or in the whole body $[3,20]$.

The relationship between low-back pain and flexion movements, speed and acceleration peak, particularly if the individual takes an asymmetrical posture or twists his trunk during the raising, [6] has been made evident in studies, highlighting the importance of the analysis of the activity.

The current article analyses the activity of jangadeiro raftsmen in the capture expedition in the urban beach of Ponta Negra, Natal-RN-Brasil emphasizing the physical demand on the stage of hauling up the nets from the ocean. The research is part of the project of extension and research Fishing Activity: tradition, ergonomics and sustainability, developed in the urban beach of Ponta Negra, Natal, RN, by GREPE - Group of Research and Extension in Ergonomics of Federam University of Rio Grande do Norte, which aims to contribute with actions for improving work conditions of raftsmen concerning issues of security, health, environment and the quality/productivity of fish through actions of management, changes in the design of the raft and the qualification of raftsmen in order to achieve sustainability of artisan fishing with rafts [15].

\section{Methodology}

It has been used as a reference the methodology of Work Ergonomic Analysis-WEA [4,10,16]. The AET comprehends a group of global, systematic and inter complementary analysis which enable the modeling of real activity in its own context and considering technical, human, environmental and social factors [16].

The demand of this research features a provoked demand, process in which the researchers aim to develop a study to identify problems which may be transformed into real demands coming from and/or authorized by the organization $[17,23]$. The process of constructing a demand is described in [19].

21 raftsmen participated in the research $(50 \%$ of the population) with whom it was aimed to immerse in their routine, following their schedule, duties and habits in order to become involved with the population and to obtain a better understanding of the activity.

The analysis of the activity has enabled the obtaining of data which were submitted to constant restitutions and validations along with the raftsmen themselves, thus allowing a refined understanding of the jangadeiro raftsmen activity and their relationships with the aspects of physical demand and their health.

In order to perform the modeling, observational and interactional methods were used, as well as a health evaluation. The observational methods include systematic open observational techniques and simulations, by using auxiliary resources to record and further analysis, such as photographic and video cameras. According to [16], observational methods have great importance for tactical and strategic reasons in WEA. Tactical for allowing records and data which will have great usefulness in some of the interactional methods. Also strategic importance allowing the team to become familiar with the ergonomics of the work situation, the jangadeiro raftsmen and their agents, and also the other people involved in the artisan fishing with rafts in Ponta Negra.

The methods and interactional techniques used were the following; social and economical questionnaire, conversational actions, spontaneous and provoked verbalizations, self confrontations and workshops ( collective analysis)

As the aim of the research is linked with the physical demand of the fishing activity, it was important to check the physical conditions of the raftsmen in order to establish relations between the fishing acitivity and its repercussions in the health of these raftsmen.

The health assessment comprised: static posture assessment by using the Sanny portable Symmetrograph; analysis of flexibility on the flex extension movement of the shoulder through the use of Sanny Portable Fleximeter and the Ischiotibial and the lumbar and ischiotibial muscle through Sanny's Wells sit and reach bench and the assessment of gripstrength with a Jamar dynamometer. The diagram of painful areas was applied [9] and the Nordic Questionnaire for the analysis of Skeletal- Muscular symptoms [13] in search of report of pain from the raftsmen. The collected data were added to a Microsoft Excell 2007 table. 


\section{Results}

\subsection{Work population}

The raftsmen of Ponta Negra Beach are male, have incomplete primary education and their families have from 3 to 7 children. Most of their ages range from 40 to 49 years old (33,33\%), from 30 to 39 and 50 to $59(28,57 \%)$. The youngest group (20 to 29 years old) has the smallest percentage $(9,52 \%)$. These data indicate a low level of work force renovation in the activity and the growing predominance of an elderly population developing an activity which demands physical strength, disposition, long and intense night shifts, long periods in repetitive and forced postures, or short moments in postures that require great strength.

The income provided from the fishing activity varies a lot for it is influenced by the period of the year ,the kind of fishing and the fact or whether the raftsman own his raft or not, more often than not being carried parallel activities to the fishing itself. Some raftsmen have a license to fish lobster and earn a minimum salary during the

closed season (december to may). For the ones who are licensed, the amount received during this period is extremely important for it complements the income, being used not only for buying food and surviving but also for purchasing equipment and tools necessary for fishing and the maintenance of the raft.

All raftsmen researched live in the village of Ponta Negra, located approximately 850 meters far from the place where rafts are docked.They all have their own home and live in masonry homes with electricity. $100 \%$ of the home have piped water and $57,1 \%$ of the homes have a water tank, $4,8 \%$ have cisterns and the remaining $(38,09 \%)$ use water provided directly by the public water supplier. The garbage collecting is done by the Company of Urban Services of Natal URBANA. The sewage is collected by the Company of Water and Sewage of RN, however, 11,9\% of the homes have a septic tank and 4,8\% have open sewage.

$57,14 \%$ of the raftsmen have already suffered some work-related accident from dealing with poisonous marine species or piercing objects or species to raft transport, specially when handlig the coconut rolls and also poor work tools, slipery deck among others.

The learning of the job from the researched raftsmen startet at an early age. $38,10 \%$ started be- tween the age of 5 and 10 years old, and $42,86 \%$ of them from 11 to 15 years old. Only two raftsmen started fishing after 20 years old. In most cases, the fishing job was passed on by other raftsmen and not by relatives, who wished their sons had followed another career. The raftsman starts his job as a proeiro( assistant), who develops basic activities for helping the capture expedition. With practice, the raftsman improves his learning and skills until he is able to manage the raft, a task normally given to the mestre (master). However, actually it is observed that it is not only necessary to have the necessary skills to be a master. Some other factors contribute to that process. One of them is what could be described as opportunity, i.e.: the raftsman who has a raft and who rents it or is hired to work in a raft as a master. Such opportunity increases the chance of the raftsman to control the raft and acquire more experience.

$28,57 \%$ of the raftsmen are active between 21 and 30 years old. The time of activity between 11 and 20 years; 31 to 40 years and over 40 years represent $23,81 \%$ of the raftsmen who participated in the research.

The raftsmen who participated in the current research are all masters. However, when questioned about their job in the period of the research, $57 \%$ of them said they were masters and $43 \%$ said they were assistants.

\subsection{Rafts}

The rafts of Ponta Negra are medium-sized, rated as paquetes, according to [21]. They are built in marine plywood and wood, they have sail or engine propulsion. The dimensions of the rafts are varied, measuring from 3,6 to $5,14 \mathrm{~m}$ length by 1,4 to $1,7 \mathrm{~m}$ width- these dimensions being defined by their owners. The use of Honda Stationary Engine is a recent innovation in the rafts of Ponta Negra. Its use began around 2005. According to reports by raftsmen, the use of the engine has brought improvements in the activity, among which a significant reductions in the sailing time, decrease in physical effort and less dependence on the wind, an indispensable factor when a sail is used. On the other hand, the use of fuel (gasoline) pollutes the ocean and increases the cost of the expedition.

\subsection{Fishing with rafts}

The fishing expeditions in Ponta Negra are made predominantly on tuesdays and saturdays, once most 
raftsmen dedicate their sundays, mondays and holidays to resting and solving personal matters, as well as the maintenance of the rafts. Most of the fishing is made with a net. However, some raftsmen might use a line and a net,only the thread, covos or manzuá (fishing traps in the shape of a basket or a cage) besides free diving. for fishing in some times of the year. Fishing with line is also used while they wait for the nets to be hauled.

The work strategy of the raftsmen is directly linked to the kind of fishing: the "come and go" and the "ice"fishing. The "come and go"fishing is the one in which raftsmen either go to the sea at dawn and return in the morning or they leave in the afternoon and return at night, depending on tidal conditions, moon fase, month of the year and weather. In the "ice" fishing, raftsmen usually leave in the beginning of the day and they may spend until 24 hours fishing. Ih this kind of fishing they use ice to store the fish and the nets can be cast to the ocean more than once at the same or different fisheries.

The kinds of propulsion used by boats are sail or engine. Depending on the weather, raftsmen may use both sail propulsion and engine during the same expedition. Sail propulsion requires the crew to have knowledge about weather conditions, specially the direction and speed of the wind, right position of the sails for a better performance and security. It demands more physical effort from the master, who is generally responsible for navigating and controlling the sail position as well as the assistant, who helps tying the sail, the bowline and in the occasional need for counterpoise in the raft, as well as wet the sail through closing its pores to increase sailing speed. The use of engine, introduced in Ponta Negra beach from 2005 has facilitated the work of raftsmen in terms of their dependence from the wind exclusively, thus reducing the duration of expedition and the physical effort in navigating. The master takes the raft himself without the help of the assistant.

The duration of one expedition varies from $3 \mathrm{~h} 30 \mathrm{~min}$ to $9 \mathrm{~h}$ depending on several factores among which: kind of expedition ("come and go" or "ice"), kind of propulsion used (engine or sail), sea conditions, location of fisheries, number of times the net is cast, effectiveness of expedition (amount of fish caught by number of nets cast) and even the presence of seaweed in the net.

The first step of the capture expedition is the transport of the engine and the fishing tools from the residence of the raftsmen to the place where the rafts are docked at the beach of Ponta Negra. Then the organization of the raft begins, they check items re- lated to security and fueling the engine. After that the raft is transported to the ocean with the help of two coconut tree trunks (rolos/rolls). When in the ocean, the raft is guided, the crew goes onboard and start the procedures for sailing- which vary according to the kind of propulsion to be used. They sail until the fishery where they cast the nets along $1700 \mathrm{~m}$ length. They anchor the raft and wait until it is time to haul the nets. During that time, they fish with line or feed themselves. Then, they haul the nets, separate the fish and store them in the internal compartiment in the raft. They sail back to the beach of Ponta Negra. The raft is taken from the ocean with the help of some assistants. They make sure the raft is docked on a safe place, clean it and organize the fishing tools. Finally they sell the fish, go back home and rest until the expedition or some other fishing-related activity. (Figure 1)

The step of hauling the nets from the ocean, which is the focus of this paper will be detailed as follows: (Figures 1, 2)

Two raftsmen are in charge of hauling up the nets, one of them at the bow of the raft- he has to pull the net moving the raft against the tide for about 1700 to 2700 meters. The olther raftsman stands in the middle of the raft to remove the fish from the net and store them in the inner compartment of the raft. $52,39 \%$ of the raftsmen report that the hauling of the net is the most tiring part of the expedition. "To pull the net and put it inside of the raft. It's kinda tiring, your spine aches, your head aches, everything aches, the back aches, one has to bend down all the time to put it inside."(raftsmen, J15).

The hauling of the nets from the ocean represents a high muscle skeletal risk for the raftsmen, once they remain long periods performing movements that demand physical strength and also forced postures [2]. Besides those, at any moment it may occur a destabilization of the raftsmen posture due to the swinging of the raft in the ocean or some occurrence during the net removal. There is a synchronism among raftsmen in the execution of these activities, for instance, at the moment one raftsman is bending to put the nets inside the inner compartment, another one pauses his activities or keeps hauling the nets to put them behind the sail bench. It is important to state that $100 \%$ of the raftsmen usually remove each net to be cast and hauled and then put it in the inner compartment ( they use from 17 to 27 nets, each one measuring 100 meters). That means that if a raft contains from 17 to 27 nets, the raftsmen will bend down from 17 to 27 times to store the nets. 


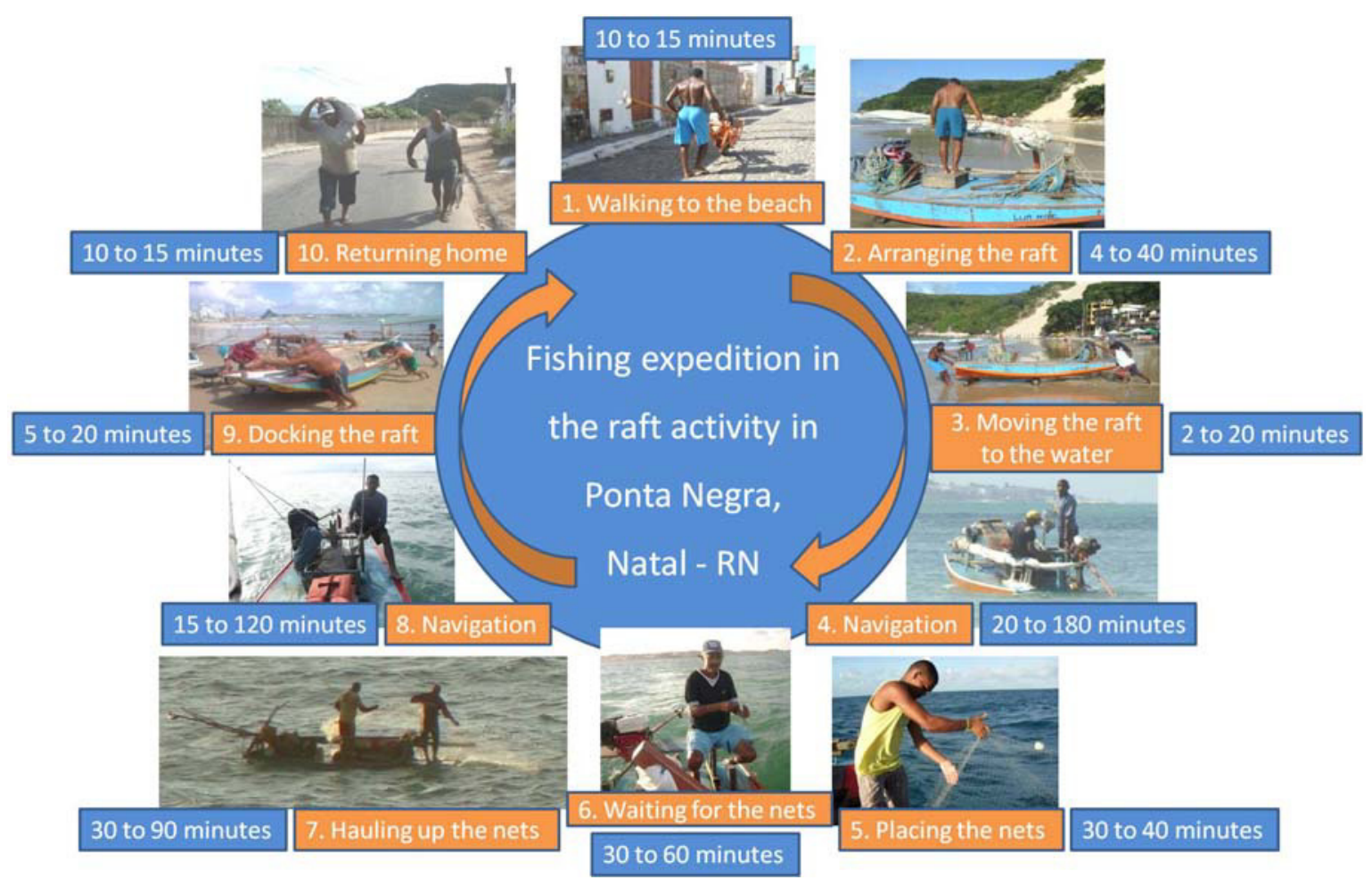

Figure 1:

Capture expedition in the raft activity in Ponta Negra, Natal-RN - Source: [1]

The raft moves against the tide while the raftsmen pull the nets until the spot where the first garoteia ( anchor) was fixed, about 1700 to 2700 meters far, depending on the amount of nets in the raft. There may be a rotation in the functions among raftsmen because of fatigue. It is important to highlight that the physical strength is directly related to the amount of fish caught and the seaweed tangled in the net thread. The physical exhaustion is increased when the net is cast more than once, which often happens in the "ice"fishing, or when there is little fish caught and the raftsmen decide to throw the net one more time.

Depending on the tidal movement, the ocean currents and the depth of the net, the flexing of the trunk may be increased. The distance from the coast is also an important factor to be considered, as demonstrated by raftsmen in a simulation (picture 2, 3), for the longer the distance from the coast, the bigger is the flexing of the spine to haul the fish from the ocean. 


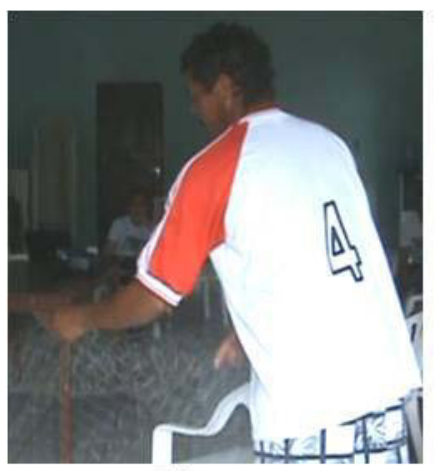

Near

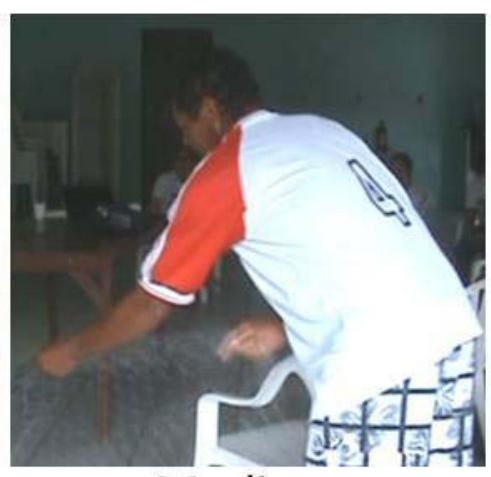

Medium

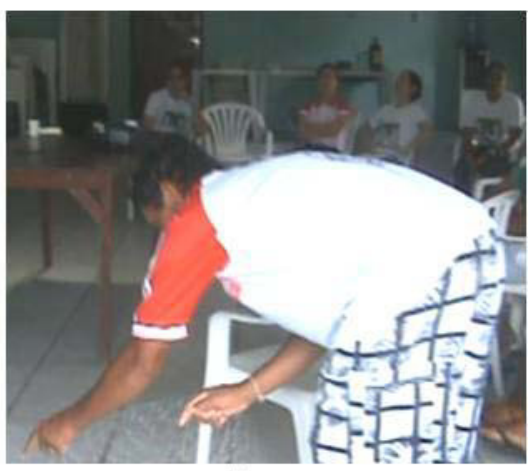

Far

Figure 2

Postures adopted for the hauling of nets from the ocean according to the distance from the coast. a Source: [1]

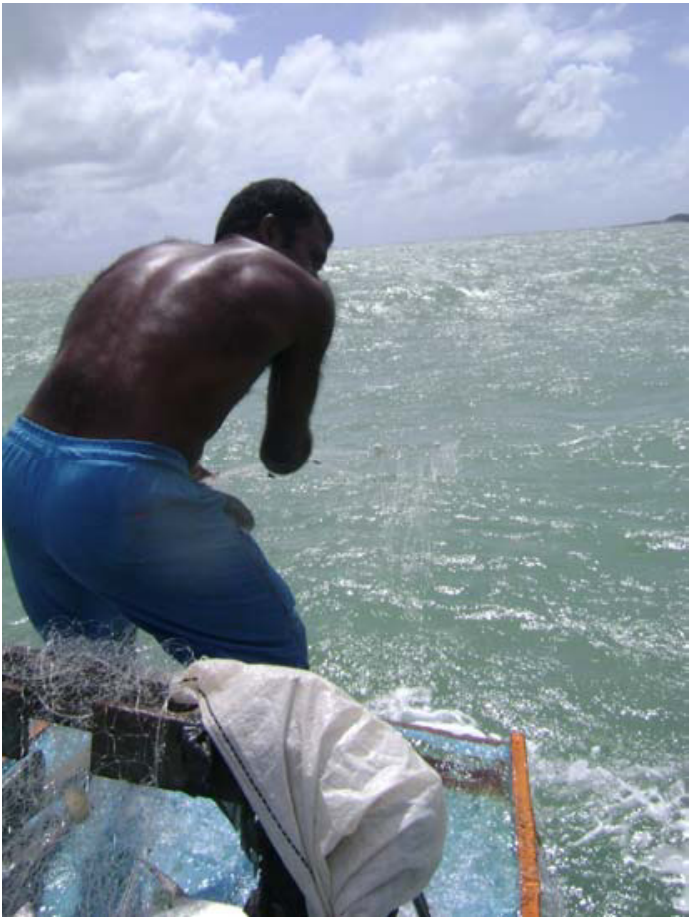

Figure 2

Hauling us the nets

Source: Projeto Jangadeiros (GREPE/UFRN)

In the testimonials of the raftsmen, the physical effort of this step is made clear: " To go to the ocean and fish, haul the net, put it down, pull, store it inside the raft.That is kinda tiring, the spine aches, the head aches, the back aches, everything aches, you keep bending over, to put the net inside ( the inner compartment of the raft). It takes more than an hour pulling it..when it is windy, when the sea is wild, then it gets heavier to pull. It takes longer because when the wind is soft it takes about an hour, when the wind is strong, the ocean is wavier, it takes around an hour and a half, an hour forty minutes. That is the hardest part."( raftsmen J15).

Besides the physical load, this step of the activity has a cognitive aspect related to the movements for stabilizing posture to maintain the balance during the movements of the raft and the sea.

In order to achieve that, raftsmen observe the movements of the sea to anticipate and constantly regulate their posture in order to keep the poise. They also perform regulating strategies during the hauling of the net so that the fish will not scape as well as to identify the captured species so as to avoid accidents as cuts or piercings in the upper limbs. Some raftsmen use gloves to haul the nets.

\subsection{3 Repercussions of the activity in the raftsmen's health}

The postural assessment reflects the consequences of the activity in the body and health of the raftsmen. These results show that the raftsmen studied have cervical spine, upper limbs and shoulders anteriorization, which is associated to the activity they perform that demands, in several moments, the flexing of the cervical spine and the shoulder and upper limb work in the body midline. The right upper limb suffers bigger reflex. It is observed a greater percentage of 
raftsmen with shoulder anteriorization and scapular protrusion. That occurs biomechanically because of the higher performance of tasks with the right shoulder, which forces the scapula.

As the human body needs balance in the orthostatic position and once there is already an anteriorization of cervical spine and upper limbs, the thoracic spine posteriorizates and the lumbar spine has its curvature increased forward.

It has been observed in the postural assessments of raftsmen that $66,66 \%$ of them have abducted feet. If we relate that with their activity, a possible answer lies in the need to increase the base of support so the body maintains its balance when standing up on the raft during the expeditions. If, during those occasions, the feet are positioned with an external rotation, then there is more of a basis for support.

About the flexibility of the flexo extension movement of the shoulders, the raftsmen have similar flexibility on both shoulders. In $50 \%$ of them, the flexibility of the left shoulder is 140 to 165 degrees and the right shoulder between 141 to 160 degrees. Compared to reference values, [12] the raftsmen would have low flexibility ( less than 207 degrees). Such decrease in the flexibility may also be explained through the activity they perform, which is mostly done under the shoulder line, specially when casting and hauling the nets from the sea.

The opposite happens with ischiotibial muscle flexibility and lumbar region, in which $75 \%$ of the raftsmen have over $23 \mathrm{~cm}$ flexiblitiy. In the raftsmen's activity, a great deal of the operations is made with the flexo extension of vertebral spine and, normally, the fishing tools are placed on the raft, that is, on the same line of the feet, thus justifying the results found in the raftsmen.

The results for manual grip showed less variability for the left grip than the right one. $50 \%$ of the raftsmen showed up to $36 \mathrm{RgF}$ on left grip. However, both have extreme values, the left grip with values above and below the concentration of data. The right grip showed the smallest extreme value. $50 \%$ of the raftsmen have $34 \mathrm{RgF}$ for right grip. $25 \%$ of the raftsmen have from 42 to $51 \mathrm{RgF}$ in the right grip and in the left grip it varies from 40 until $52 \mathrm{RgF}$. It is important to state that the highest value was for left hand grip, although the lowest value was for the right hand.

About the results on the Pain Diagram, 23,8\% of the raftsmen reported feeling some pain before the beginning of the fishing expedition, whereas when applying the Nordic questionnaire $95,24 \%$ of the raftsmen reported feeling some pain on the last seven days and $100 \%$ in the last twelve months.

The part of the body with highest pain incidence on the last few days is the lumbar vertebral spine ( $71,43 \%)$, preceded by knees ( $52,38 \%)$, ankle and feet $(33,33 \%)$. The right elbow has shown no pain according to the reports; however, the left elbow had $4,76 \%$ reports of pain.

Similarly, in the past 12 months, lumbar spine and the knees have the two highest levels of pain in raftsmen( $80,95 \%$ e $57,14 \%$ respectively). However, it is noticeable that $57,14 \%$ of the raftsmen reportedly have pains in the neck, which may be linked to the navigation itself and to the great demand for visual attention during navigation in search for objects that may collide with the vessel and damage its hull or plastic bags that may tangle the props and suddenly stop it, which causes risk of the raftsmen falling in the ocean. There was no report of pain on the left elbow.

\section{Analysis and discussions}

The population of raftmen who fish using rafts as a vessel is characterized by people who started such activity when children or teenagers, following their parents and gransparents' occupation and who are not managing to pass it on to the new generation, who aim for new professional perspectives and many times are stimulated by their parents to do so, for even though they are proud of being fishermen and having expertise on the job, they consider it to be a very hard and underpaid activity.

The hauling of the nets from the ocean during the fishing expedition using rafts was pointed by $52,39 \%$ of the fishermen as being the hardest task of the job. It represents a high musclekeletal risk for the raftmen, once they spend long periods doing movements that demand physical strength and forced postures, more often than not twisting the trunk. Besides that, at any moment there might occur the destabilization of the raftman's posture due to the movement of the raft in the ocean, or some other intercurrence that demands muscular strength from the human body to maintain the balance.

It has been highlighted the high percentage of reports of muscular skeletal pain in the spine, legs and arms. The constant painful situations related to the need to fish to support the family and also the lack of orientation on how to correctly do the activity have made the pain evolved to chronic states, and in some 
cases to the necessity or surgical procedures, mostly herniated lumbar discs. Such factor denotes a recurring issue in the workman's health, which, as made clear in one of the raftman testimonial: "of the government was to retire the workman because of his spine, a lot of people would have retired, for all I see is people complaining of their spines" (raftsmen, J21).

\section{References}

[1] A. Jaeschke. Oportunidades de melhorias ergonômicas das exigências físicas da atividade jangadeira em Ponta Negra, Natal-RN, Dissertação, Universidade Federal do Rio Grande do Norte, 2010

[2] A. Jaeschke, T.V. Souza and M. C. W. Saldanha. Expedição de captura na atividade jangadeira em Ponta Negra, Natal-RN: uma análise preliminar das posturas. In: Congresso Brasileiro de Ergonomia | Abergo 2010: Anais do XVI, 2010, Rio de Janeiro. Anais XVI Congresso Brasileiro de Ergonomia: III Congresso Latino. Rio de Janeiro : ABERGO, (1), (2010),. p. $1-6$

[3] A. V. Dall'oca. Aspectos socioeconômicos, de trabalho e de saúde de pescadores do Mato Grosso do Sul. Campo Grande, Dissertação, Universidade Federal do Mato Grosso do Sul, 2004.

[4] A. Wisner. Por dentro do trabalho: ergonomia método e técnica, FTD/ Oboré, ed., São Paulo, 1987.

[5] A.L.S. Pinto et al. Saúde e Segurança do pescador. Fundacentro Pernanbuco, 2007. Disponível em:http://200.198.202.145/seap/Jonathan/Cadernos/Saude $\% 20$ e\%20Seguranca\%20miolo.pdf. Acesso em: 28/02/09.

[6] D. Chaffin et al. Biomecânica ocupacional. Ergo, Ed. Belo Horizonte, 2001.

[7] D. G. Neto, R. C. Cordeiro and JR. V. Haddad. Acidentes do trabalho em pescadores artesanais da Região do Médio Rio Araguaia, Tocantins, Brasil. in. Cad. Saúde Pública, Rio de Janeiro, 21(3), (2005), pp. 795-803.

[8] E.G. Pimenta and M.C. Vidal. Condições de trabalho e segurança nas embarcações pesqueiras: uma análise dos acidentes. In: Carneiro, A. M. et al (Org.) O Trabalho da Pesca: Segurança, Saúde e Integração (contribuições dialógicas para a reestruturação do setor pesqueiro no Brasil), Pro Uni-Rio / Unilagos ed., Rio de Janeiro, 2000, p. 77.

[9] E.N. Corlett and I. Manenica. The efects and meansurement of working postures. Aplied Ergonomics. 11(1), (1980), pp. 7-16,

[10]F. Guérin et al. Compreender o trabalho para transformá-lo: A prática de ergonomia. Edgard Blucher LTDA, ed, São Paulo, 2001.

[11]F.R, Marques. Uma visão contextual da pesca comercial: sobrepesca e estatística de produção pesqueira em Cabo Frio RJ In: Carneiro, A. M. et al (Org.) O Trabalho da Pesca: Segurança, Saúde e Integração (contribuições dialógicas para a reestruturação do setor pesqueiro no Brasil). Pro Uni-Rio / Unilagos ed., Rio de Janeiro, 2000, p. 61.

[12] G.A. Monteiro. Manual de utilização do flexímetro Sanny. 2000. Disponível em: http://www.Sanny.com.br/downloads/manual_flex.pdf. Acesso em: 09 maio de 2009.

[13]I. Kourinka et al. Standardised Nordic questionnaires for the analysis of musculoskeletal symptoms. Aplied Ergonomics. 18( 3), (1986), pp. 233-237.
[14]IBAMA. Boletim estatístico da pesca marítima e estuarina do estado do Rio Grande do Norte 2007. IBAMA, Natal, 2008.

[15]J. P. Castello. O futuro da pesca da aquicultura marinha no Brasil: a pesca costeira. Ciência e Cultura, 62(3), (2010), pp. 32-35.

[16]M. C. Vidal. Guia para Análise Ergonômica do Trabalho na empresa: Uma metodologia realista, ordenada e sistemática, Virtual Científica, ed., Rio de Janeiro, 2008.

[17]M. C. W. Saldanha. Ergonomia de concepção de uma plataforma Line Oriented Flight Training (LOFT) em uma companhia aérea brasileira: a relevência do processo de construção social de projeto,Tese, Universidade Federal do Rio de Janeiro, 2004.

[18]M. C. W. Saldanha,. Projeto Jangadeiros: tradição, ergonomia e sustentabilidade. Projeto de Pesquisa e Extensão. GREPE/UFRN. Natal-RN, 2007.

[19] M. C. W. Saldanha et al. Ergonomia e sustentabilidade na atividade jangadeira: construção das demandas ergonômicas na praia de Ponta Negra-RN. $1^{\circ}$ Simpósio de ergonomia e sustentabilidade na atividade jangadeira marítima e costeira. 2010. 22p.

[20]M. F. M. Rosa and U. A. Mattos. O. A saúde e os riscos dos pescadores e catadores de caranguejos da Baía de Guanabara. Revista Ciência e Saúde Coletiva. Disponível em: http://www.abrasco.org.br/cienciaesaudecoletiva/artigos/artigo int.php?id_artigo=1798. Acesso em: 20 de fevereiro de 2009.

[21] $\bar{N}$. B. G. Araújo. Jangadas. Banco do Nordeste do Brasil S.A ed., Fortaleza, 1985.

[22] R. Benevides. Pescadores abandonam o mar. In: Diário do Nordeste - Cidade - Frota pesqueira. Disponível em: http://diariodonordeste.globo.com/materia.asp? codigo $=443609$. Acesso em: 16 de fevereiro de 2007.

[23]R. J. M. Carvalho. A padronização situada como resultante da ação ergonômica em sistemas complexos: estudos de caso numa companhia aérea nacional a propósito da implantação de um treinamento CRM-LOFT, Tese, Universidade Federal do Rio de Janeiro, 2005.

[24]R.S. Teles and M.C. Vidal, Espaços de trabalho nas embarcações pesqueiras regionais: abordagem prospectiva das condições de uso. In: Carneiro, A. M. et al (Org.) O Trabalho da Pesca: Segurança, Saúde e Integração (contribuições dialógicas para a reestruturação do setor pesqueiro no Brasil), Pro Uni-Rio / Unilagos ed., Rio de Janeiro, 2000, pp. 105-106.

[25] S. M. M. C. Silva, Caracterização da Pesca Artesanal na Costa do Ceará, Brasil, Tese, Universidade Federal de São Carlos, 2004. Disponível em: http://www.bdtd.ufscar.br/tde_busca/arquivo.php?codArquivo $=395>$ Acesso em 14 set. 2008 .

[26]T. C. C. Santos and J. B. D. Câmara. GEO Brasil 2002Perspectivas do Meio Ambiente no Brasil, (2), Edições IBAMA, Brasília, 2002.

\section{Fomentation:}

CNPq, PROEXT MEC-SESU, PROEX-UFRN, Bolsas de mestrado CAPES e CNPq, Iniciação Científica CNPq e PROPESQ e, extensão PROEX-UFRN 